\title{
AEM2017 \\ Validation of autonomous renewable energy hybrid wind/photovoltaic/RHFC prototype for the cell tower industry using MATLAB/Simulink
}

\author{
Gerard Jansen ${ }^{\mathrm{a}, \mathrm{b} *}$, Zahir Dehouche ${ }^{\mathrm{a}, \mathrm{b}}$, Richard Bonser ${ }^{\mathrm{b}}$, Harry Corrigan ${ }^{\mathrm{c}}$ \\ ${ }^{a}$ Centre for Energy and Built Environment Research, Brunel University London, United Kingdom, UB8 3PH, UK \\ ${ }^{b}$ College of Engineering, Design and Physical Sciences, Brunel University London, United Kingdom, UB8 3PH, UK \\ ${ }^{c}$ SolarBotanic Ltd. 2SolarBotanic Ltd, Kemp House 152 City Road, London EC1V 2NX, UK
}

\begin{abstract}
A large number of telecommunication base stations operate on unreliable grid or no grid at all, and rely on batteries or diesel generators for primary or back-up energy. This paper proposes an autonomous renewable energy micro-grid, using Solar Photovoltaics and Wind Turbine to generate electricity, and a Regenerative Hydrogen Fuel Cell as backup power for up to 10 days. The system is validated using MATLAB/Simulink software and real-life weather data and optimized for a $25 \mathrm{~kW}$ micro-grid near Dakar, Senegal. The simulations show a smart load-following system that instantaneously recognizes the cheapest source of electricity to power the load. Levelised Cost of Electricity based on the outcomes of the MATLAB/Simulink model show the economic potential of an RHFC as back-up for micro-grids, allowing cheap and reliable electricity to rural areas in developing countries, with a LCOE of $6.71 \mathrm{p} / \mathrm{kWh}$, RHFC is by far the cheapest back-up for this application.
\end{abstract}

* Corresponding author. Tel.: +44 7534077847.

E-mail address: Gerard.Jansen@brunel.ac.uk 


\section{Introduction}

According to almost 750 experts and decision-makers in the World Economic Forum's multistakeholder communities, failure of climate change mitigation and adaption is now the single biggest global risk, ahead of weapons of mass destruction, and water crises [1]. In developing countries and remote areas, where there is no (reliable) grid connection, the challenges are even bigger. Worldwide, almost 1.2 billion people are living without electricity [2]. In addition to that, in developing countries, diesel generators are often used for electricity production and come with environmental, health and cost concerns. Electricity is fundamental for many essential services that increase income in rural areas such as; agriculture, clean drinking water, health care, education, communications, and quality of life [3]. It is critical for developing countries to have access to cheap, reliable electricity and give them the opportunity to leap-frog towards modern energy generating technologies in order to mitigate environmental issues.

Mobile telephone penetration has a significant impact on growth in both the upper-low-income and the lowincome countries in Africa [4]. Deploying reliable communication infrastructure is key to allow developing countries to develop and can be achieved by sharing knowledge of technologies with these countries. The increase in cell phone penetration has led to an increase of energy consumption of cell phone towers. Nowadays, over $75 \%$ of cell phone towers in Nigeria rely on Diesel generators or batteries for reliable power supply. Concerns of costs, theft, and environmental issues have raised the attention of deploying renewable energy technologies [5]. GSMA has estimated that 10,890 sites in Nigeria and Ghana alone could convert to green power deployments [6]

Combining the increase in mobile telephone penetration and the challenge to have access to cheap, reliable electricity, already deployed cell phone tower structures can be used to deploy renewable energy sources such as Solar Photovoltaics (PV) and Wind Turbines. As these renewable energy sources are highly intermittent, adequate back-up is required to provide reliable electricity supply to the cell phone tower all throughout the whole year. Diesel generators or battery packs are commonly used for this, but concerns of costs, theft, and environmental issues have raised the attention of deploying sustainable technologies.

A Regenerative Hydrogen Fuel Cell (RHFC) is proposed to secure a reliable back-up power system. The RHFC system uses excess renewable electricity to generate hydrogen gas from liquid water in an electrolyser. The hydrogen is stored in a tank and dispatched to the PEMFC to generate electricity when desired [7]

The electrolyser is a device that generates hydrogen and oxygen by splitting water using electricity. The water flows through a series of porous graphite plates, applying DC power to this plates enables water to break down into Hydrogen and Oxygen. The electrolyser has to fulfil requirements such as high efficiency, low cost, high flexibility, and large range of operation.

The proposed hydrogen storage is a metal-hydride technology. Hereby, the hydrogen is stored in a solid-state at low pressure; a safer, more convenient method compared to high-pressure compression and liquefaction technologies [8]. In a metal-hydride storage tank, a porous nanostructured metal is used to absorb hydrogen. The hydrogen is stored in a solid form inside the crystal structure of the metal. The reaction happening during this hydriding process is exothermic which means heat is released. The amount of heat depends on the pressure of hydrogen. Hydrogen coming from the Electrolyser is pressurized up to 30 bar. The porous nanostructured materials commonly used for metalhydride storage are capable of absorbing hydrogen at pressures below 5 bar. To de-hydride the metal-hydride, heat should be applied to bring hydrogen back to a gaseous state to be supplied to the PEMFC.

A PEM fuel cell is used to generate electricity from hydrogen, with only water and heat as by-products. The electricity can be used on-site or distributed into a (micro-) grid. If necessary, the heat can be used for district heating.

RHFC systems have several characteristics that are well-suited to energy storage. The energy capacity and power capacity of a RHFC can be configured independently. Using hydrogen as an energy carrier provides flexibility and a dramatically higher energy density than any other energy storage medium [9]. Furthermore, fuel cells have been proven to work in harsh weather environments [10] and provide power when electricity is either not enough or unavailable from the renewable sources [11], causing the RHFC to be cost and maintenance effective in the long term and applicable in various climatic conditions [12]

First, the renewable energy hybrid wind/photovoltaic/RHFC is modelled in MATLAB/Simulink to validate its reliability in energy supply throughout the year. The model will be used to optimize installed capacity of each of the components used. After that, outputs of the MATLAB/Simulink model are used to calculate the expected Levelised Cost of Electricity (LCOE) when using an RHFC as back-up in a fictional micro-grid near Dakar, Senegal. As a comparison, the LCOE of the RHFC is compared to that of Lithium-Ion battery pack and diesel generator as a backup for renewable energy sources, and a stand-alone diesel generator powering the complete load. 


\section{Theoretical study}

To validate the characteristics of the system, such as ability to follow the load and storage capacity, a Simulink model is made. In this model, the RHFC unit is coupled to a Solar PV array and Wind Turbine. This model helps selecting the operation characteristics of the control system and helps size the system based on the local climate and requirements. The Simulink model is set up respecting the technologies' characteristics.

\subsection{Solar Photovoltaics}

The Solar PV model uses input from ambient temperature and solar irradiance to calculate the generated current and voltage of the module. Modules are connected in series or parallel to form an array to achieve the desired current and voltage for the application. The current generated by the Solar PV array is calculated from equation 1.

$$
I_{P V}=N_{P} I_{P H}-N_{P} I_{0}\left[\exp \left(\frac{\frac{V}{N_{S}}+\frac{I R_{S}}{N_{P}}}{n V_{T}}\right)-1\right]-I_{S H}
$$

Where, $N_{P}$ is the number of modules in parallel, $I_{P H}$ is the module photo-current $(\mathrm{A}), I_{0}$ is the dark saturation current (A), $V$ is the module operating Voltage $(\mathrm{V}), N_{S}$ is the number of modules in series, $I$ is the module operating current $(\mathrm{A}), R_{S}$ is the series resistance $(\Omega), n$ is the ideality factor of the diode (1.2), $V_{T}$ is the thermal voltage $(\mathrm{V})$, and $I_{S H}$ is the shunt current $(\mathrm{A})$. The shunt current is found by equation 2 :

$$
I_{S H}=\frac{V \cdot \frac{N_{P}}{N_{S}}+I R_{S}}{R_{S H}}
$$

The dark saturation current varies with the cell temperature and is found by equation 3 :

$$
I_{0}=I_{R S}\left[\frac{T}{T_{r e f}}\right]^{3} \exp \left[\frac{q E_{g 0}}{n k}\left(\frac{1}{T}-\frac{1}{T_{\text {ref }}}\right)\right]
$$

Where, $I_{R S}$ is the module reverse saturation current (A), $T$ is the operating temperature $(\mathrm{K}), T_{r e f}$ is the reference temperature $(298.15 \mathrm{~K}), E_{g 0}$ is the band gap energy of silicon semiconductor $(1.1 \mathrm{eV}), q$ is the electron charge (1.6 $\left.10^{-19} \mathrm{C}\right)$, and $k$ is the Boltzmann's constant $\left(1.3805 \cdot 10^{-23} \mathrm{~J} / \mathrm{K}\right)$. The thermal voltage is found by equation 4 and the module photo-current is found by equation 5 :

$$
\begin{gathered}
V_{T}=\frac{k T}{q} \\
I_{P H}=I_{S C}+K_{i}\left(T-T_{r e f}\right) \cdot \frac{G}{1000}
\end{gathered}
$$

Where, $I_{S C}$ is the short-circuit current of the module at operating conditions $(6.48 \mathrm{~A}), K_{i}$ is the short-circuit current at Standard Testing Conditions, and $G$ is the solar irradiance $\left(\mathrm{W} / \mathrm{m}^{2}\right)$. The module reverse saturation current is found by:

$$
I_{R S}=\frac{I_{S C}}{\left[\exp \left(\frac{q V_{O C}}{N_{S} n k T}\right)-1\right]}
$$

Where, $V_{O C}$ is the module open circuit voltage $(69.5 \mathrm{~V})$. 


\subsection{Wind Turbine}

The wind model uses wind speed data adjusted to the hub height of the wind turbine to calculate the power generated from the wind. The wind speed is adjusted by using equations 7 :

$$
V_{W}=V_{\text {ref }}\left(\frac{H}{H_{\text {ref }}}\right)^{\alpha}
$$

Where, $V_{W}$ is the wind speed at hub height $(\mathrm{m} / \mathrm{s}), V_{\text {ref }}$ is the reference wind speed $(\mathrm{m} / \mathrm{s}), H$ is the hub height $(40 \mathrm{~m})$, $H_{\text {ref }}$ is the height at which $V_{\text {ref }}$ is measured $(10 \mathrm{~m})$, and $\alpha$ is an empirically derived coefficient that varies dependent upon the stability of the atmosphere conditions $(0.14)$.

The power captured from the wind is then calculated using equation 8:

$$
P=\frac{1}{2} \rho A V_{W}^{3}
$$

Where, $\rho$ is the density of air $\left(1.223 \mathrm{~kg} / \mathrm{m}^{3}\right)$ and $A$ is the area of the rotor $\left(50.26 \mathrm{~m}^{2}\right)$. The wind turbine is couplet to a permanent magnet generator and AC/DC inverter to convert the power in the wind into useful electrical energy.

\subsection{Regenerative Hydrogen Fuel Cell}

Theoretically, the electrolyser works as a reversed fuel cell. In the fuel cell, the voltage drops when current increases, where in the electrolyser the voltage rises when current increases as per equation 9 and 10 .

$$
\begin{gathered}
V_{F C}=V_{\text {Nernst }}-E_{a c t}-E_{o h m}-E_{\text {conc }} \\
V_{\text {ele }}=V_{\text {Nernst }}+E_{a c t}+E_{\text {ohm }}+E_{\text {conc }}
\end{gathered}
$$

Where, $V_{F C}$ is the fuel cell voltage $(\mathrm{V}), V_{\text {ele }}$ is the electrolyser voltage $(\mathrm{V}), V_{\text {Nernst }}$ is the Nernst voltage $(1.229 \mathrm{~V})$, $E_{\text {act }}$ is the activation overpotential $(\mathrm{V}), E_{\text {ohm }}$ is the ohmic overpotential $(\mathrm{V})$, and $E_{\text {conc }}$ is the concentration overpotential. The activation overpotential is found by:

$$
E_{\text {act }}=-2.3 \frac{R T}{\alpha F} \log \left(i_{0}\right)+\frac{R T}{\alpha F} \log (i)
$$

Where, $R$ is the universal gas constant $\left(8,314 \mathrm{~J} \mathrm{kmol}^{-1} \mathrm{~K}^{-1}\right), T$ is the operating temperature $(\mathrm{K}), \alpha$ is the charge transfer coefficient, $F$ is the Faraday's constant $\left(96,485 \mathrm{~A} \mathrm{~s} \mathrm{~mol}^{-1}\right), i_{0}$ is the exchange current density $\left(\mathrm{A} \mathrm{cm}^{-2}\right)$, and $i$ is the operating current density $\left(\mathrm{A} \mathrm{cm}^{-2}\right)$. The ohmic overpotential is found by:

$$
E_{\text {ohm }}=i R_{i}
$$

Where, $R_{i}$ is the cell internal resistance $\left(\Omega \mathrm{cm}^{-2}\right)$. The concentration overpotential is found by:

$$
E_{\text {conc }}=\frac{R T}{n F} \ln \left(\frac{i_{L}}{i_{L}-i}\right)
$$

Where, $n$ is the number of electrons exchanged, and $i_{L}$ is the limiting current density $\left(\mathrm{A} \mathrm{cm}^{-2}\right)$. Table 1 shows the additional parameters used for simulation of the Fuel Cell and Electrolyser model. 
Table 1: Additional input variables for Fuel Cell and Electrolyser model

\begin{tabular}{crr}
\hline Parameter & Value Fuel Cell & Value Electrolyser \\
\hline $\boldsymbol{\alpha}$ & 1 & 0.23 \\
$\boldsymbol{i}_{\mathbf{0}}$ & $3 * 10^{-6} \mathrm{~A} \mathrm{~cm}^{-2}$ & $4.5^{*} 10^{-2} \mathrm{~A} \mathrm{~cm}^{-2}$ \\
$\boldsymbol{R}_{\boldsymbol{i}}$ & $0.15 \Omega \mathrm{cm}^{-2}$ & $0.21 \Omega \mathrm{cm}^{-2}$ \\
$\boldsymbol{i}_{\boldsymbol{L}}$ & $1.6 \mathrm{~A} \mathrm{~cm}^{-2}$ & $2.2 \mathrm{~A} \mathrm{~cm}^{-2}$ \\
\hline
\end{tabular}

A variable load is implemented in the control system in order to calculate excess or shortage of renewable energy supply and determine the cheapest source of electricity to power the load.

\subsection{Levelised Cost of Electricity}

The Levelised Cost of Electricity (LCOE) is an important financial parameter to measure cost-effectiveness of energy generating technologies. Although LCOE calculations are highly sensitive to the underlying data, it offers a comparison between projects and technologies. LCOE aims to provide comparisons of different technologies with different project size, life time, different capital cost, return, risk, and capacities. It is an economic assessment of the total cost to build and operate a power-generating asset over its lifetime divided by the total energy output of the asset over that lifetime [93]. The LCOE is calculated by:

$$
\operatorname{LCOE}\left(\frac{€}{k W h}\right)=\frac{\text { Lifecycle cost }(€)}{\text { Lifetime energy }(k W h)}
$$

The system is sized to provide year-round electricity to the inhabitants without power outages due to the intermittence of the Solar PV and Wind energy sources. Three cases are studied for storage and back-up power for the micro-grid are analysed: RHFC, Battery and Diesel generator (Genset). Additionally, LCOE for a micro-grid entirely powered by a Genset is studied. Information about the system sizing is shown in Table 2. Table 3 on page 6 shows the capital costs for the technologies used for calculation of the systems lifecycle cost.

Table 2: System sizing data

\begin{tabular}{lrll}
\hline System lifetime & 20 & $\mathrm{yrs}$ & {$[13]$} \\
Inflation rate & 2.3 & $\%$ & {$[14]$} \\
Installed capacity PV & 70 & $\mathrm{~kW}_{\text {DC,peak }}$ & \\
Installed capacity wind & 91 & $\mathrm{~kW}_{\text {rated }}$ & \\
Installed capacity FC & 25 & $\mathrm{~kW}_{\text {rated }}$ & \\
Installed capacity Storage & 240.02 & $\mathrm{Kg} \mathrm{H}_{2}$ & \\
Installed capacity EL & 35 & $\mathrm{~kW}_{\text {rated }}$ & \\
Installed capacity Genset & 25 & $\mathrm{~kW}_{\text {rated }}$ \\
\hline
\end{tabular}


Table 3: Initial capital cost for selected technologies

\begin{tabular}{lrrll}
\hline Solar PV & $£$ & $1,241.11$ & per kWDC,peak & {$[15]$} \\
Wind Turbine & $£$ & $1,000.00$ & per kWrated & {$[16][17]$} \\
Fuel Cell & $£$ & $1,180.00$ & per kWrated & {$[18]$} \\
Electrolyser & $£$ & 940.00 & per kWrated & {$[19]$} \\
Hydrogen storage & $£$ & 333.00 & per Kg H2 stored & {$[20]$} \\
Diesel Generator & $£$ & 650.00 & per kWrated & {$[21]$} \\
Diesel & $£$ & 1.02 & per Litre & {$[21]$} \\
Battery & $£$ & 180.00 & per kWh & {$[22]$} \\
\hline
\end{tabular}

Besides capital costs, costs for shipping, local taxes and import charges apply to deploy an energy system in Senegal as shown in Table 4. During operation, technologies efficiency drops due to wear of materials, contamination etc. With a long system lifetime, these degradations should be taken into account as they influence the system energy generation or capacity over time. The annual degradation rates for the used technologies are shown in Table 5 . Operation and maintenance (O\&M) costs are essential for LCOE calculations as they will increase costs over the lifetime and are effected by inflation rates. O\&M costs of the selected technologies are shown in Table 6. For comparison with lithium-ion battery and diesel generator, assumed constant efficiencies of $92.5 \%$ round-trip and $43 \%$ energy conversion for the Genset are used.

Table 4: Assumed additional costs for deployment

\begin{tabular}{lr}
\hline Cost per container & $£ 1,700.00$ \\
Import charges & $10 \%$ \\
VAT & $18 \%$ \\
\hline
\end{tabular}

Table 5: Degradation rates for selected technologies

\begin{tabular}{lrr}
\hline Solar PV degradation & $0.50 \%$ & {$[23]$} \\
Wind Turbine degradation & $1.60 \%$ & {$[24]$} \\
Fuel cell degradation & $0.90 \%$ & {$[25]$} \\
Electrolyser degradation & $0.90 \%$ & {$[25]$} \\
Battery degradation & $1 \%$ & {$[26]$} \\
Diesel generator & $1 \%$ & {$[27]$} \\
\hline
\end{tabular}

Table 6: O\&M costs for selected technologies

\begin{tabular}{|c|c|c|c|}
\hline Solar PV & $1.50 \%$ & of Capital cost & {$[28]$} \\
\hline Wind Turbine & $£ 50.00$ & per $\mathrm{kW}$ installed & [29] \\
\hline Fuel Cell & $£ \quad 0.03$ & per operating hour & {$[30]$} \\
\hline Electrolyser & $£ \quad 0.03$ & per operating hour & {$[30]$} \\
\hline Battery & $1 \%$ & of Capital cost & {$[31]$} \\
\hline Storage tank & $0.50 \%$ & of Capital cost & \\
\hline Genset & $£ 0.78$ & per operating hour & [32] \\
\hline
\end{tabular}


The first case analysed is for a system with an RHFC back-up system. In this system, excess energy is sent to an electrolyser to convert water into hydrogen. The hydrogen is then stored in an AB5-based metal-hydride for safe storage at low pressure and ambient temperature. Using an iterative process, the optimum storage capacity was found to be $8,000 \mathrm{kWh}$ of hydrogen stored. As shown in Figure 2, this gives sufficient amount of storage to have hydrogen available at all time during the year. Based on the lower heating value of hydrogen $(120 \mathrm{MJ} / \mathrm{kg}=33.33 \mathrm{kWh} / \mathrm{kg})$, the amount of hydrogen stored is then $240.02 \mathrm{~kg}$.

The second case analysed is for using a battery pack as back-up system. The battery size in ampere-hours (Ah) is calculated by:

$$
C_{n}=\frac{E_{L} \cdot F}{M D O D \cdot T C F \cdot V_{n}}
$$

Where $C_{n}$ is the battery capacity in Ah, $E_{L}$ the average daily load, $F$ the days of storage required, $M D O D$ the maximum depth of discharge for the battery without damaging, TCF the temperature correction factor (vary with battery type, lower temperatures limit the maximum allowable depth of discharge), and $V_{n}$ is the battery voltage output. Chosen is a Lithium-Ion battery because of its stability at higher temperatures in Senegal [34]. Table 7 shows the values used for battery sizing calculation parameters in equation 15.

Table 7: Battery size calculation values

\begin{tabular}{cr}
\hline Parameter & Value \\
\hline $\boldsymbol{E}_{\boldsymbol{L}}$ & $360 \mathrm{kWh} /$ day \\
$\boldsymbol{F}$ & 10 days \\
$\boldsymbol{M D O D}$ & $80 \%$ \\
$\boldsymbol{T C F}$ & 1.056 \\
$\boldsymbol{V}_{\boldsymbol{n}}$ & $48 \mathrm{~V}$ \\
\hline
\end{tabular}

The third case analysed is this of a diesel generator back-up system. A diesel generator is common to use in SubSaharan Africa, despite the high fuel costs, noise and emissions.

A fourth case is added to see how the renewable energy micro-grid compares to a micro-grid based on fossil fuel energy generation using only a diesel generator. Even though it is common to have a small diesel generator per household in Sub-Saharan Africa, it is becoming more popular to buy a bigger diesel generator with a small community to share costs and profits and hence lower LCOE compared to the reported 33 pence per $\mathrm{kWh}$ for household diesel generators [21].

\section{Results and discussion}

Figure 1 shows the MATLAB/Simulink schematic. Solar Photovoltaics and a Wind Turbine are used to generate electricity to power the load of the $25 \mathrm{~kW}$ micro-grid. Excess electricity is send to an Electrolyser to generate Hydrogen $\left(\mathrm{H}_{2}\right)$. The $\mathrm{H}_{2}$ is stored as a solid in a Metal Hydride hydrogen tank at low pressure to avoid parasitic losses from compression. Whenever the load requirements are higher than the Solar PV/Wind generated, the Polymer Electrolyte Membrane (PEM) fuel cell supplies back-up power. 


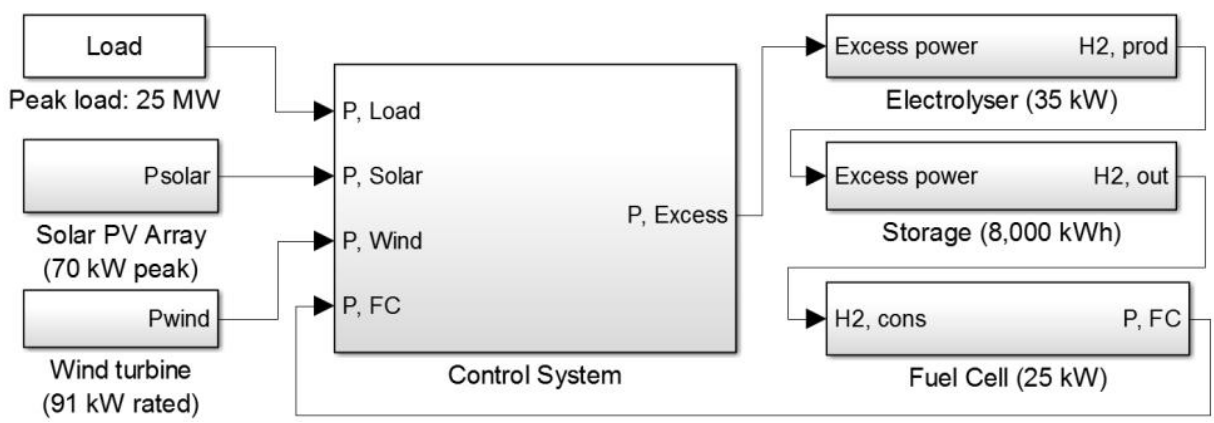

Figure 1: Schematic illustration of the MATLAB/Simulink model

Figure shows the hydrogen state-of-charge throughout the year. It can be seen that during fall, when generation from Solar PV and Wind are low, the hydrogen storage gives sufficient storage to back-up the renewables and power the fuel cell. The electrolyser receives enough excess energy from the renewables to recharge the hydrogen storage reservoir.

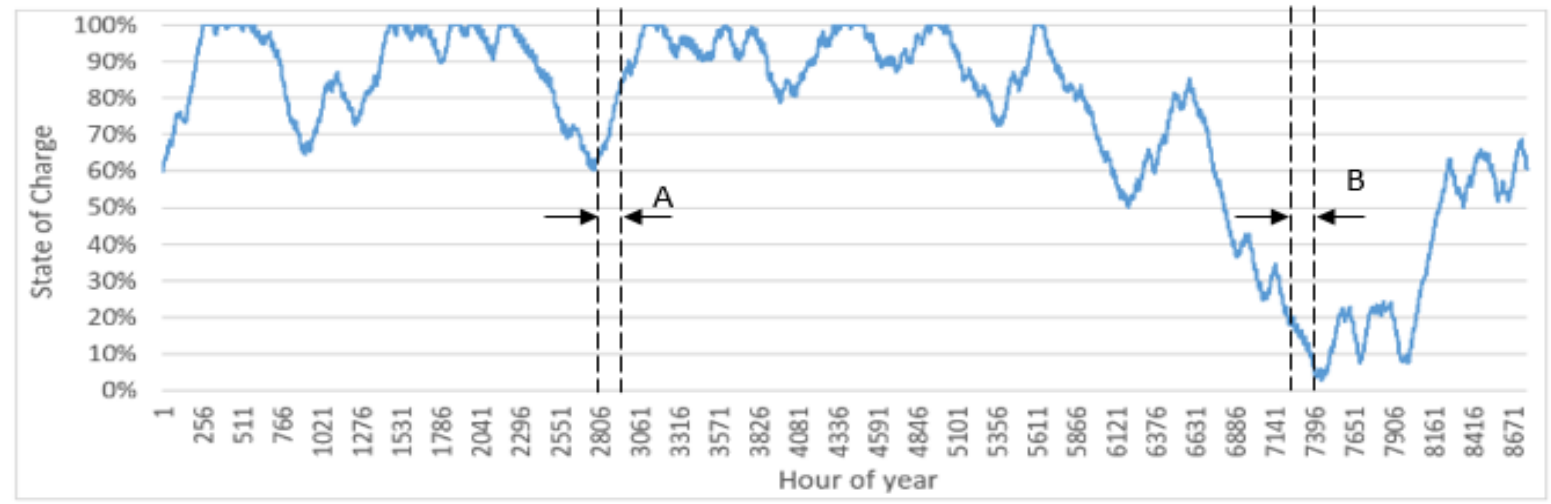

Figure 2: Hydrogen State-of-Charge throughout the year

Figure 2 shows two simulation weeks. During week A, from 26 April to 2 May, Wind and Solar PV generate plenty excess energy to recharge the hydrogen reservoirs. During this week, the load is mainly powered by renewables and the fuel cell is barely required as a back-up. Therefore, the reservoir will be recharged for periods with less renewable energy available such as in week B. Week B, from 27 October to 2 November, is a period with low renewable energy generation. During the day, some Solar PV is available to power the load, but Wind energy is lacking. Therefore, the fuel cell is required to power the load. This can be seen in a depletion of the hydrogen storage reservoir, whose state-of-charge drops significantly during this week.

Zooming in on a single day, it can be seen in Figure 3 that the fuel cell successfully follows the load when there is no energy available from renewable sources. The smart control system recognizes when electricity is generated by the renewables. In this case, the fuel cell will be tuned down so that the renewables have priority in powering the load. This is done for two reasons. First, this allows to keep hydrogen storage charged in case of emergencies and second, the electricity from renewables is cheaper per unit $(\mathrm{p} / \mathrm{kWh})$ and therefore the load is always powered by the cheapest source of electricity available. From the output of the simulations, LCOE is calculated. Including import charges and transport costs, the LCOE for the different scenarios are presented in Figure and

Table 8.

As a back-up system for this configuration, the RHFC provides the lowest LCOE in combination with the PV/Wind system. Despite the high capital cost of the RHFC, the long lifetime provides a lower LCOE due to the amount of energy delivered over its lifetime Also its operation and maintenance cost are low, and because of its low maintenance requirements, logistics and reduced site-visits further simplify the autonomous system. 

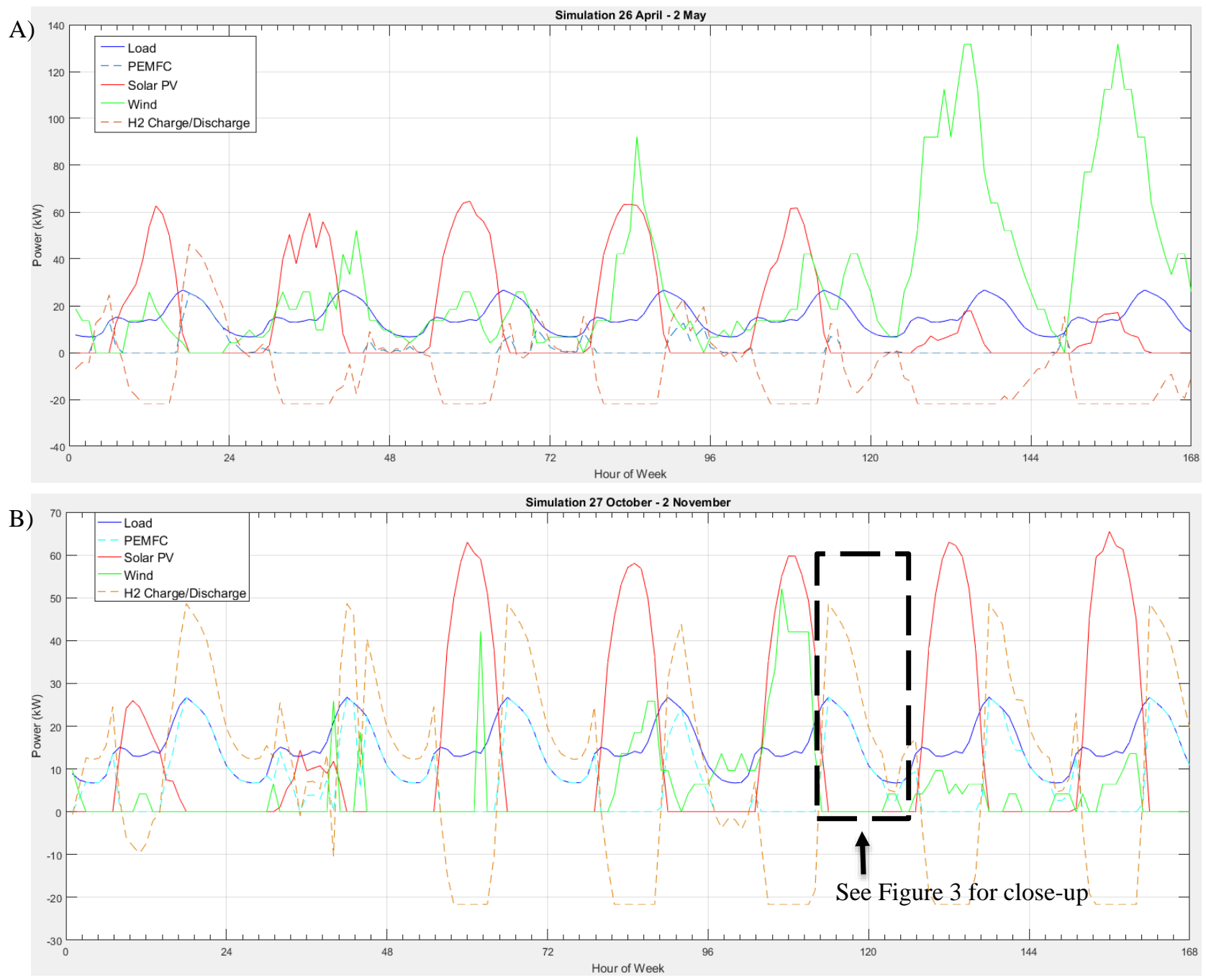

Figure 2: MATLAB/Simulink simulation results for the weeks of A) 26 April - 2 May and B) 27 October - 2 November. When renewable energy is available, this is send to power the load. When there is an excess of renewable energy generated, this is send to the electrolyser to produce hydrogen $\left(\mathrm{H}_{2}\right)$, as is visible when the hydrogen charge is represented by a 'negative discharge' of the Solid-Hydrogen Energy Storage modules. When renewable energy generation is not sufficient to power the load, the PEM Fuel Cell covers the load requirements.

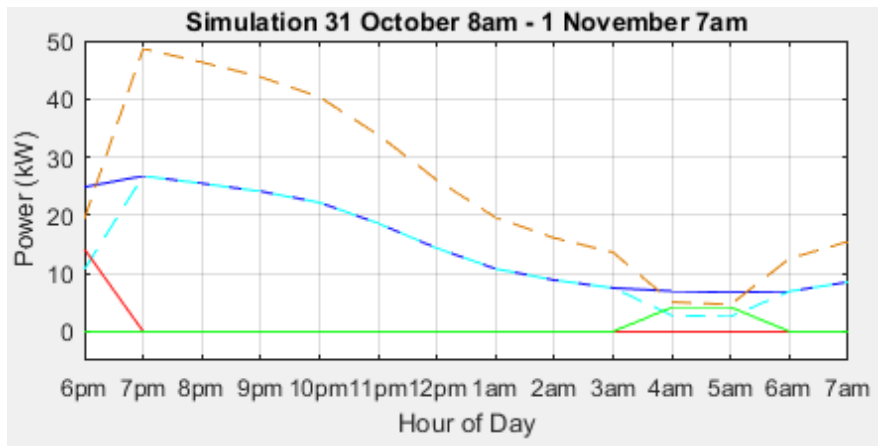

Figure 3: Zoom-in on load-following Fuel Cell 
Table 8: Levelised Cost of Electricity (p/kWh) for 25kW small micro-grid near Dakar, Senegal

\begin{tabular}{lrrrr}
\hline & $\begin{array}{r}\text { PV/Wind/ } \\
\text { RHFC }\end{array}$ & $\begin{array}{r}\text { PV/Wind/ } \\
\text { Battery }\end{array}$ & $\begin{array}{r}\text { PV/Wind/ } \\
\text { Genset }\end{array}$ & Genset \\
Capital cost & 3.72 & 8.17 & 2.65 & 0.29 \\
O\&M & 1.76 & 3.38 & 2.99 & 3.14 \\
Fuel cost & - & - & 2.81 & 12.63 \\
Import & 0.37 & 0.82 & 0.27 & 0.03 \\
VAT & 0.67 & 1.47 & 0.48 & 0.05 \\
Shipping & 0.19 & 0.27 & 0.23 & 0.34 \\
Total & $\mathbf{6 . 7 1}$ & $\mathbf{1 4 . 1 1}$ & $\mathbf{9 . 4 2}$ & $\mathbf{1 6 . 1 8}$ \\
\hline
\end{tabular}

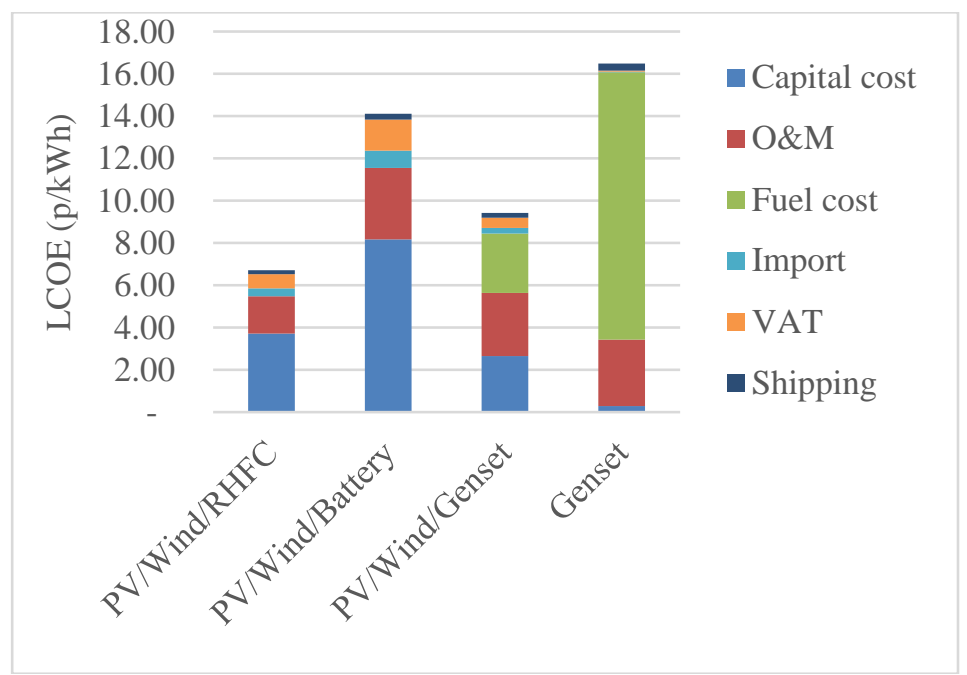

Figure 5: Levelised Cost of Electricity (p/kWh) for 25kW small micro-grid near Dakar, Senegal

\section{Conclusion}

An autonomous renewable energy generating and back-up system is proposed and successfully validated using MATLAB/Simulink and experimental testing of individual components and the integrated system. The system provides the full load requirements of the cell phone tower throughout the year and can be scaled accordingly to provide electricity for small communities near the cell phone tower.

LCOE calculations based on the outcomes of the MATLAB/Simulink model show the economic potential of an RHFC as back-up for micro-grids, allowing cheap and reliable electricity to rural areas in developing countries, with a LCOE of $6.71 \mathrm{p} / \mathrm{kWh}, \mathrm{RHFC}$ is by far the cheapest back-up for this application.

\section{Acknowledgement}

This study is sponsored by and carried out in collaboration with SolarBotanic Ltd.

\section{References}

[1] World Economic Forum, “The Global Risks Report 2016,” World Economic Forum, Geneva, 2016.

[2] International Energy Agency, "Energy access database - World Energy Outlook (WEO),” 2016. [Online]. Available: http://www.worldenergyoutlook.org/resources/energydevelopment/energyaccessdatabase/. [Accessed 1106 2017].

[3] A. Vaccaro, R. Baseil, H. Hagras, M. Ho, P. Krein, R. Larsen, Glenn McKnight, V. Modi, A. E. Pascual, K. Passino, K. Perusich and A. Zobaa, "Reliable Electric Power for Developing Countries," Humanitarian Technology Challenge, In Press. 
[4] H. K. Chavula, "Telecommunications development and economic growth in Africa," Information Technology for Development , vol. 19, no. 1, pp. 5-23, 2013.

[5] L. Graves, "Energy priorities and strategies for Africa's 'Big Four' towercos,” 0205 2017. [Online]. Available: https://www.towerxchange.com/energy-priorities-and-strategies-for-africas-big-four-towercos/. [Accessed 08062016 ].

[6] GSMA, "Powering Telecoms: West Africa Market Analysis," GSMA, London, 2013.

[7] F. Barbir, "PEM electrolysis for production of hydrogen from renewable energy sources," Solar Energy, vol. 78, no. 5, pp. 661-669, 2005.

[8] N. Rusman and M. Dahari, "A review on the current progress of metal hydrides material for solid-state hydrogen storage applications," International Journal of Hydrogen Energy, vol. 41, pp. 12108-12126, 2016.

[9] T. Ghosh and M. Prelas, Energy Resources and Systems: Volume 2: Renewable Resources, 2 ed., Dordrecht: Springer Science+Business Media B.V., 2011.

[10] K. Mahadevan, K. Judd, H. Stone, J. Zewatsky, A. Thomas, H. Mahy and D. Paul, "Identification and Characterization of Near-term Direct Hydrogen Proton Exchange Membrane Fuel Cell Markets," Battelle Memorial Institute, Columbus, 2007.

[11] R. Bücken, "From CO2 to H2O: Telecommunications go green," Fuel Cell Bulletin, vol. 2012, no. 8, pp. 12-14, 2012.

[12] M. A. Pellow, C. J. Emmott, C. J. Barnhart and S. M. Benson, "Hydrogen or batteries for grid storage? A net energy analysis," Energy Environ. Sci., vol. 2015, no. 8, pp. 1938-1952, 2015.

[13] NREL, "Distributed Generation Renewable Energy Estimate of Costs," National Renewable Energy Laboratory, 02 2016. [Online]. Available: http://www.nrel.gov/analysis/tech_lcoe_re_cost_est.html. [Accessed 1704 2017].

[14] Bank of England, “Inflation Report,” Bank of England, London, 2017.

[15] Department of Energy \& Climate Change, "Solar PV cost data," 2605 2016. [Online]. Available: https://www.gov.uk/government/statistics/solar-pv-cost-data. [Accessed 201704 2017].

[16] M. Ragheb, “The Economics of Wind Energy,” M. Ragheb, Illinois, 2017.

[17] IRENA, "The power of change: Solar and Wind cost reduction potential to 2025," International Renewable Energy Agency, Abu Dhabi, 2016.

[18] J. S. A. W. D. P. Jason Marcinkoski, “DOE Hydrogen and Fuel Cells Program Record,” U.S. Department of Energy, 2015.

[19] Strategic Analysis Inc. \& NREL, "Techno-economic Analysis of PEM Electrolysis for Hydrogen Production,” 27 02 2014. [Online]. Available: https://energy.gov/sites/prod/files/2014/08/f18/fcto_2014_electrolytic_h2_wkshp_colella1.pdf. [Accessed 2604 2017].

[20] DOE, "Hydrogen Storage," 2017. [Online]. Available: https://energy.gov/eere/fuelcells/hydrogen-storage. [Accessed 2704 2017].

[21] S. Baurzhan and G. P. Jenkins, "Off-grid solar PV: Is it an affordable or appropriate solution for rural electrification in Sub-Saharan African countries," Renewable and Sustainable Energy Review, vol. 60, pp. 1405-1418, 2016.

[22] M. K.-M. P. B. C. J. V Viswanathan, "National Assessment of Energy Storage for Grid Balancing and Arbitrage," U.S. Department of Energy, Oak Ridge, 2013.

[23] Sunpower, "SunPower® X-Series Residential Solar Panels," 2017. [Online]. Available: https://us.sunpower.com/sites/sunpower/files/media-library/data-sheets/ds-x22-series-360-residential-solar-panels.pdf. [Accessed 0425 2017].

[24] I. Staffell and R. Green, "How does wind farm performance decline with age?," Renewable Energy, vol. 66, pp. 775-786, 2014.

[25] H. D. C. A. G. S. Jennifer Kurtz, "V.F.10 Fuel Cell Technology Status-Degradation,” in FY 2015 Annual Progress Report, Golden, DOE, 2015, pp. 174-179.

[26] NREL, "Backup Power Cost of Ownership Analysis and Incumbent Technology Comparison,” National Renewable Energy Laboratory, 2014.

[27] S. Baurzhan and G. Jenkins, "On-Grid Solar PV versus Diesel Electricity Generation in Sub-Saharan Africa: Economics and GHG Emissions," Sustainability, vol. 9, no. 372, pp. 1-15, 2017.

[28] NREL, "Distributed Generation Renewable Energy Estimate of Costs," 02 2016. [Online]. Available: http://www.nrel.gov/analysis/tech_lcoe_re_cost_est.html. [Accessed 2504 2017].

[29] NREL, "Cost and Performance Assumptions for Modeling Electricity Generation Technologies," National Renewable Energy Laboratory, Golden, 2010.

[30] I. T. Ender Ozden, "PEM fuel cell degradation effects on the performance of a stand-alone solar energy system," International Journal of Hydrogen Energy, vol. In Press, pp. 1-9, 2017.

[31] Lazard, "Lazard's levelized cost of energy storage - version 1.0," Lazard, 2015.

[32] HOMER, "HOMER Energy Report," 2007 2016. [Online]. Available: http://usersupport.homerenergy.com/customer/en/portal/articles/2188634-diesel-o-m-costs. [Accessed 24042017 ].

[33] Shakti, "Diesel Generators: Improving Efficiency and Emission Performance in India," ICF International, 2014.

[34] AllCell Technologies LLC, "A Comparison of Lead Acid to Lithium-ion in Stationary Storage Applications," AllCell Technologies LLC, 2012. 